\title{
Chapter 14 \\ Following the Father Steps in the Bowels of the Earth: The Ichnological Record from the Bàsura Cave (Upper Palaeolithic, Italy)
}

\author{
Marco Avanzini, Isabella Salvador, Elisabetta Starnini, Daniele Arobba, \\ Rosanna Caramiello, Marco Romano, Paolo Citton, Ivano Rellini, \\ Marco Firpo, Marta Zunino, and Fabio Negrino
}

\begin{abstract}
The chapter summarizes the new results of the Bàsura Revisited Interdisciplinary Research Project. The integrated interpretation of recent archaeological data and palaeosurface laser scans, along with geoarchaeological, sedimentological, geochemical and archaeobotanical analyses, geometric morphometrics and digital
\end{abstract}

M. Avanzini $(\bowtie) \cdot$ I. Salvador

MUSE, Museo delle Scienze, Trento, Italy

e-mail: marco.avanzini@muse.it; isabella.salvador@muse.it

E. Starnini

Department of Civilizations and Forms of Knowledge, Università di Pisa, Pisa, Italy

Soprintendenza Archeologia Belle Arti e Paesaggio per la Città Metropolitana di Genova e le province di Imperia, La Spezia e Savona, Genoa, Italy

e-mail: elisabetta.starnini@unipi.it

D. Arobba

Museo Archeologico del Finale - Istituto Internazionale di Studi Liguri, Finale Ligure Borgo SV, Italy

e-mail: arobba@museoarcheofinale.it

R. Caramiello

Dipartimento di Scienze della Vita e Biologia dei Sistemi, Università di Torino, Turin, Italy e-mail: rosanna.caramiello@unito.it

M. Romano

Evolutionary Studies Institute (ESI), School of Geosciences, University of the Witwatersrand, Johannesburg, South Africa

e-mail: marco.romano.univ@gmail.com

P. Citton

CONICET-Consejo Nacional de Investigaciones Científicas y Técnicas, Buenos Aires,

Argentina

e-mail: pcitton@unrn.edu.ar

I. Rellini · M. Firpo

Department of Earth, Environment and Life Science (DISTAV), University of Genoa,

Genoa, Italy

e-mail: rellini.ivano@dipteris.unige.it; firpo@dipteris.unige.it 
photogrammetry, enabled us to reconstruct some activities that an Upper Palaeolithic human group led inside a deep cave in northern Italy within a single exploration event about $14 \mathrm{ka}$ calBP. A complex and diverse track records of humans and other animals shed light on individual- and group-level behaviour, social relationship and mode of exploration of the uneven terrain. Five individuals, composed of two adults, an adolescent and two children, entered the cave barefoot lightening the way with a bunch of wooden sticks (Pinus t. sylvestris/mugo bundles). While proceeding, humans were forced to move on all fours, and the traces they left represent the first report of crawling locomotion in the global human ichnological record. Anatomical details recognizable in the crawling traces show that no clothing was present between limbs and the trampled sediments. Our study demonstrates that very young children (the youngest about 3 years old) were active members of the human groups, even in apparently dangerous and social activities, shedding light on behavioural habits of Upper Palaeolithic populations.

Keywords Upper Palaeolithic - Cave exploration - Animal and human footprints . Morphometric analysis · Human locomotion - Cave bear extinction

\title{
Introduction
}

The Bàsura Cave (Grotta della Bàsura) opens at $186 \mathrm{~m}$ a.s.l., about $1 \mathrm{~km}$ north of Toirano (Savona) at the foot of Mount Carmo of Loano (436253.433 E; 4887689.739 N) in western Liguria (Fig. 14.1).

The discovery of the inner rooms of the Bàsura Cave represented one of the most spectacular events of the Italian prehistoric research of the 1950s of the twentieth century (Giacobini 2008). Up to that time, only the atrial part of the cavity was known where, towards the end of 1890, archaeological remains of Neolithic and late Roman Age were discovered (Maineri 1985).

The inner rooms, developed along a main branch of about $400 \mathrm{~m}$ in length, became accessible in 1950, when a group of young boys broke a stalagmite column placed a few dozen meters from the entrance (Tongiorgi and Lamboglia 1954; Blanc 1960; Lamboglia 1960). The cave revealed its palaeontological value following a site inspection by Virginia Chiappella (1952). Chiappella identified several remains of Ursus spelaeus and traces of human frequentation (footprints, charcoals, digital tracks, lumps of clay adhering to the walls).

\author{
M. Zunino \\ Servizio Grotte di Toirano, Comune di Toirano (Savona), Italy \\ e-mail: martazunino@tiscali.it \\ F. Negrino \\ Dipartimento di Antichità, Filosofia, Storia (DAFIST), Università degli Studi di Genova, \\ Genoa, Italy \\ e-mail: fabio.negrino@unige.it
}




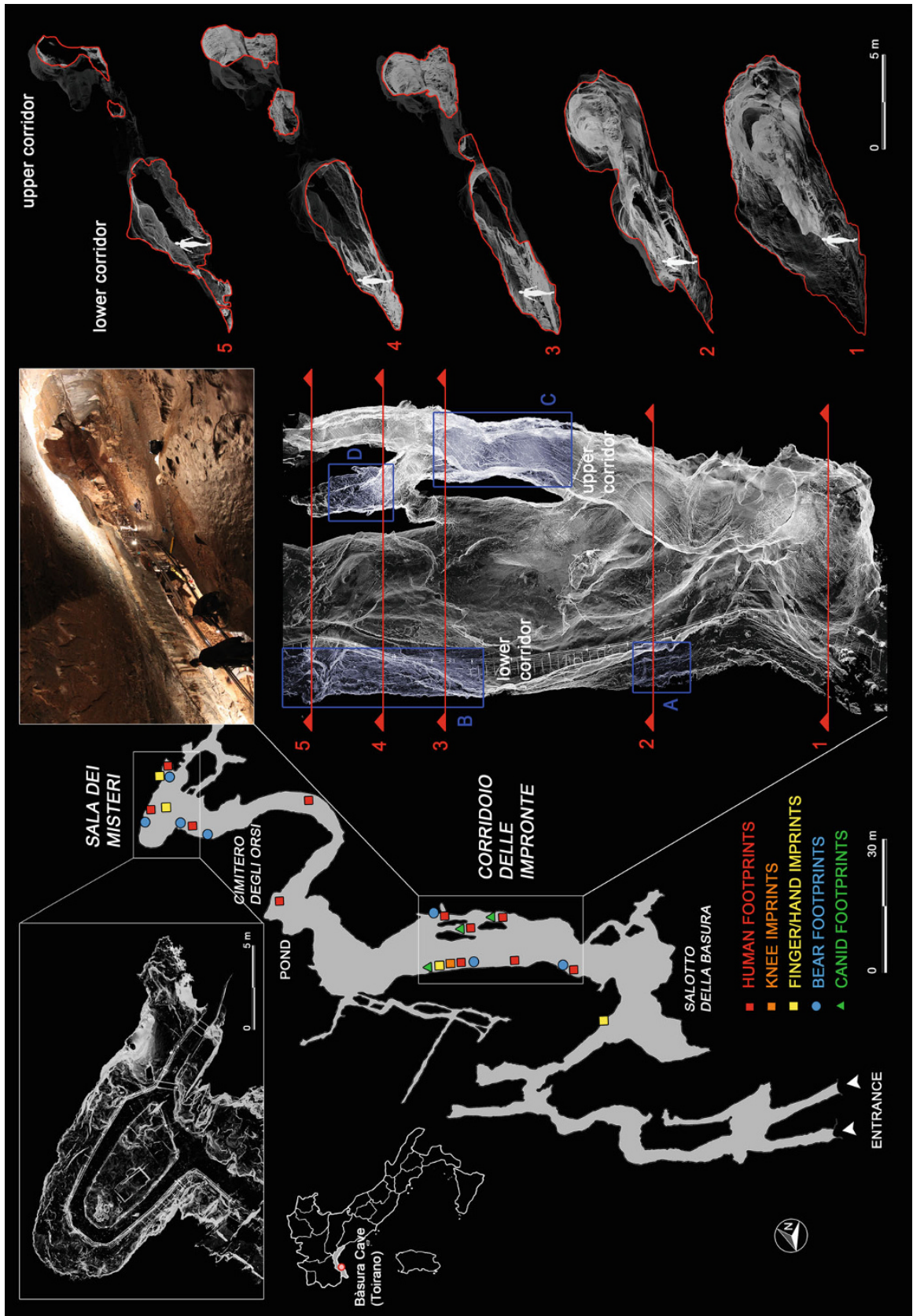

Fig. 14.1 Planimetry of the Bàsura Cave and location of human, bear and canid footprints. White rectangles enclose the three-dimensional reconstructions, obtained via laser scanner, of the innermost room (Sala dei Misteri - left) and the main gallery (Corridoio delle Impronte - right) of the cave, where the human footprints are preserved. Cross-sections obtained from the threedimensional reconstruction of the main gallery are highlighted in red and show the branching of the lower and upper corridors, respectively. Blue rectangles indicate the four areas within the main gallery where most of the human footprints are concentrated (A and B for the lower corridor, C and $\mathrm{D}$ for the upper corridor) 
Unfortunately, uncontrolled access to the cave of visitors and numerous curious peoples that followed the days of its discovery led to the destruction of most of the prehistoric human and animal footprints imprinted in the clay of the cave floor (Blanc et al. 1960; De Lumley and Giacobini 1985). Only those tracks consolidated enough and/or covered by calcite concretions survived. In the following years, other footprints were inadvertently damaged during the construction of the touristic pathway for the opening of the cave to the public (De Lumley and Giacobini 1985).

\section{Human Footprints of the Bàsura Cave: Previous Studies}

A first study of human footprints from the Bàsura Cave was conducted by Pales (1960), based on the observation of the originals and 13 plaster casts of the bestpreserved specimens found in various sectors of the cave. Pales recognized two footprints size classes: the first characterized by an average foot length of $22.5 \mathrm{~cm}$ and the second with a length of $27 \mathrm{~cm}$. The analysis of the foot bone architecture of the footprint authors, and their apparently association with the remains of Ursus spelaeus, led Pales to attribute the footprints to Neanderthal-type authors. Subsequent reanalysis of the context (De Lumley et al. 1984), coupled by the first set of absolute dating, placed the prehistoric frequentation of the Bàsura Cave in the Upper Palaeolithic, between 12,000 and 14,000 years BP (De Lumley et al. 1984; De Lumley and Giacobini 1985). Radiocarbon dating of charcoal samples, collected from the trampled surface, provided a more precise age for the human frequentation of the cave at 12,340 $\pm 160 \mathrm{BP}(14,534 \pm 417$ calBP) (Molleson et al. 1972; Molleson 1985).

According to the interpretation proposed by Blanc (1960), some individuals attended the cave traveling towards the inner rooms and imprinted traces of feet, hands, and knees, sometimes overlapped or deformed by the subsequent passage of bears and wolves. Based on the ichnological study of Pales, Blanc proposed that the innermost Sala dei Misteri (Fig. 14.1) was reached by a group of some individuals, among which a juvenile. Moreover, Blanc (1960) described from the same room a group of seven footprints identified by heel tracks, imprinted on the floor a few centimetres far from the main wall of the room, in which numerous small lumps of clay were stuck. This evidence has been interpreted as the traces of prehistoric ritual activity, in particular possible initiatory rites perhaps involving young hunters. This hypothesis seemed supported by the presence at the end of the Sala dei Misteri of a stalagmite concretion (defined by Blanc (1960) as acephalous sphinx or zoomorphic stalagmite), whose surfaces are almost entirely covered by finger fluting drawing sinuous furrows, tracked intentionally by several individuals.

In 2014, the Soprintendenza Archeologia, Belle Arti e Paesaggio per la Città Metropolitana di Genova e le province di Imperia, La Spezia e Savona, Genova, has 
launched a multidisciplinary study of the cave (Bàsura Revisited) in cooperation with the Municipality of Toirano under the direction of two of the present authors (ES, MZ) (resp. Elisabetta Starnini), involving a careful reanalysis of the prehistoric traces left in the cave, the taphonomy and chronology of the cave bear deposit and the first stratigraphic excavation in the deposit of the innermost room, namely, the Sala dei Misteri.

\section{Geology of the Bàsura Cave}

The Bàsura Cave is part of an ancient and larger karst system carved in a Middle Triassic limestone-dolomite massif (Collina dei Roccai, $400 \mathrm{~m}$ a.s.l). Deeply entrenched valleys separate it from other ridges. It entirely developed in the Costa Losera and overlain Dolomie di San Pietro dei Monti Fm. of Anisian to Ladinian age (Menardi Noguera 1984). The karst system comprises four distinct levels. The upper level, hydrologically inactive, corresponds to Grotta del Colombo ( $247 \mathrm{~m}$ a.s.l.) while the lower to Bàsura Cave (186 m a.s.l.). The network of cavities is developed along bedding planes, and NW-SE or WNW-ESE trending tectonic structures (fractures and joints) related to the main phase of the Alpine-Apennine chain uplift which took place within the Plio-Pleistocene.

The speleogenesis of the cave systems was recently interpreted by Chiesa et al. (2019). The genesis of these karst systems may be related to a weak thermalism and possibly to the rising of mineralized waters which are fed by freshwater via a complex regional hydrogeological flow path (hypogenic caves). In fact, a thermal spring $\left(20{ }^{\circ} \mathrm{C}, \mathrm{Q} \approx 100 \mathrm{l} / \mathrm{s}\right)$ is present in Toirano at $70 \mathrm{~m}$ a.s.l. along the contact (fault) between the permeable Triassic carbonate formation and impermeable quartzites (Calandri 2001). Moreover, the main horizontal passages of the cave system are short and terminate with a vertical conduit (feeder), and several forms of small and large sizes, generated by condensation-corrosion processes above the water table, can be observed along the cave ceiling and walls (e.g. sets of coalesced ceiling cupolas, dome pits). However, remains of fluvial sediments are preserved throughout the caves, indicating the overlap of epigenetic process cycles.

The ages of the different stages of the karst evolution are poorly constrained, but they can be placed within the framework of the Early Pleistocene morphologic evolution of the area, during which depression of the sea level played an important role.

The Bàsura Cave presents a sub-horizontal trend and has a total spatial development of $890 \mathrm{~m}$ and height difference of $+20 /-22 \mathrm{~m}$ with respect to the entrance. The air temperature of the caves is constant (about $16{ }^{\circ} \mathrm{C}$ ), and the relative humidity, during all the seasons, is nearby saturation (Bruzzone et al. 2006). Water is still present in two little lakes, but the water dripping is relatively widespread 
everywhere. Different fluvial sediments and speleothems fill the passage, and sometimes large flowstone masses were deposited over the older sediments.

Flooding dynamics and cave geometry produced two different situations for sediment deposition and transport inside the cave. Detrital sediment comprising silty clay and well-sorted sandy sediment are most abundant on the floor of the Sala dei Misteri. Coarse lithologies comprising gravel-sized and larger $(>2 \mathrm{~mm})$ grains include a few fragments of bear bones. The sandy fraction comprises allogenic, surface-derived siliciclastic sediment. The Sala dei Misteri appears to have undergone episodic filling and erosion as a result of catastrophic storms.

Sediment in the Corridoio delle Impronte comprises a large mud fraction and includes many coarse lithic fragments which are mainly carbonates (calcite and dolomite), suggesting an autogenic origin. Here, the trampled substrate is poorly consolidated and superimposed on a stalagmite crust. At the time when humans and other large mammals left their traces, the cave substrate differed in different areas of the cave. In some areas, the substrate was plastic, and in other areas, it was waterlogged or submerged. Differing moisture content of the substrate accounts for the variable preservation of detail of the tracks (e.g. registration of plantar arch, heel and metatarsal regions, digit tips, track walls), particularly of the associated extra-morphologies (e.g. expulsion rims, slipping traces). The surface of the substrate and the footprints are cross-cut by mud cracks, suggesting a loss of moisture in sediments after trampling. Carbonate crusts (comprising both calcite and dolomite) cover many of the footprints in areas subjected to more intense dripping. Iron and manganese oxide coatings were found in the crust, probably due to repeated immersion in ponded water.

\section{Ichnology of Bàsura Cave}

\section{Footprints, Handprints, Finger and Human Body Traces}

A total of 117 human traces, including complete footprints, rear foot imprints, fore foot imprints, knee traces, finger traces and body traces, were recorded in the Bàsura Cave (Fig. 14.2) (Romano et al. 2019).

The morphology and dimensions indicated five distinct morphotypes. Morphotype 1 includes footprints with a mean length of $13.55 \pm 0.49 \mathrm{~cm}$. It shows a not well-developed plantar arch but a heel area proportionally wider than longer tracks. These characters, coupled with the morphology and dimensions of digit traces, indicate an early ontogenetic stage of the producer. Morphotype 2 comprises footprints with a mean length of $17 \mathrm{~cm}$ and can be easily distinguished from morphotype 1 on the basis of a more pronounced plantar arch. This morphotype is characterized by footprints with a wide range of variability, which is correlated to the nature of the substrate (Webb et al. 2006; Morse et al. 2013). Morphotype 3 includes footprints with a mean length of $20.83 \pm 0.51 \mathrm{~cm}$ and is featured by a pronounced plantar arch (Fig. 14.2, SM15). This area is characterized by a medial embayment 

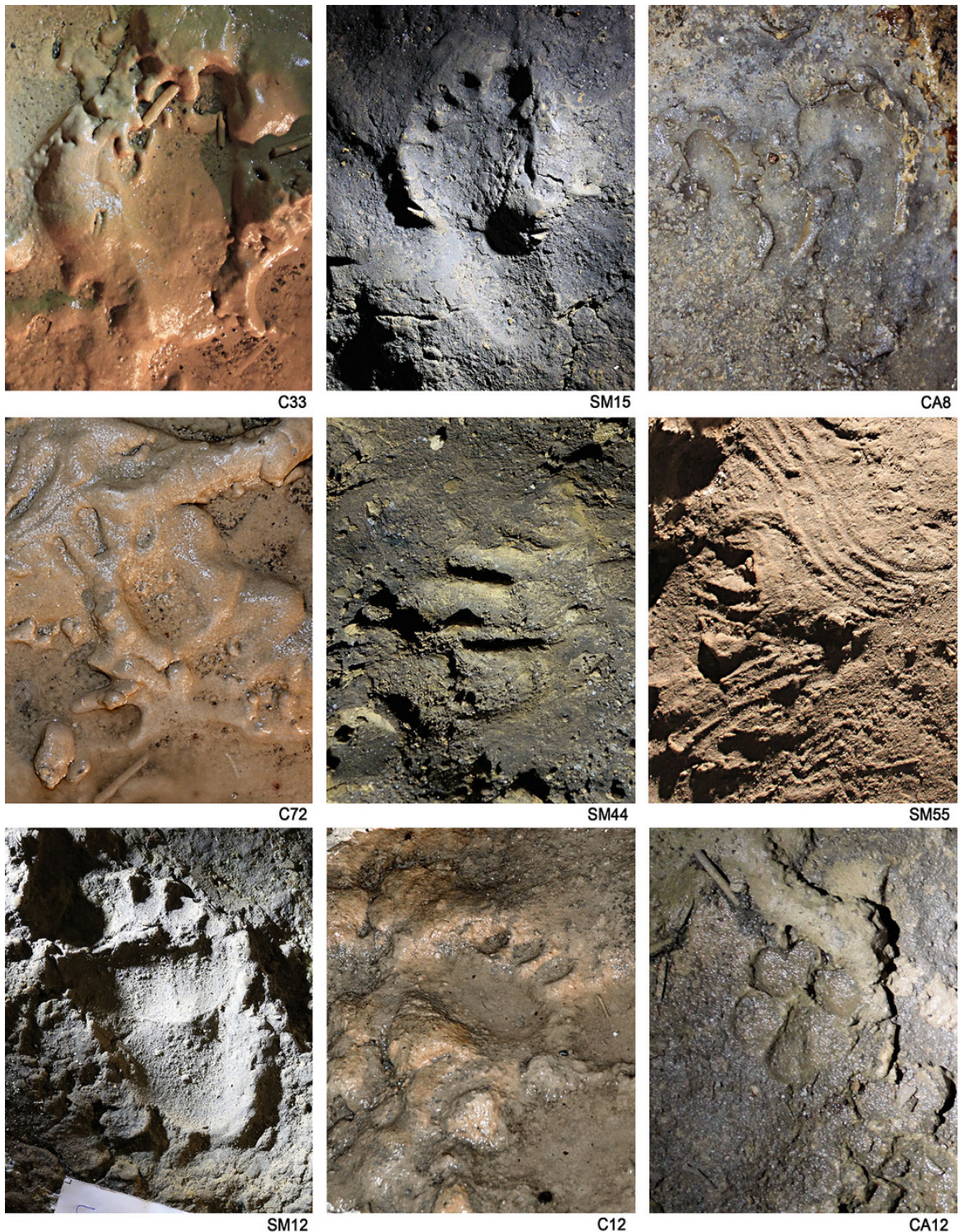

Fig. 14.2 Selected traces from the Bàsura Cave. C33, human footprint referred to morphotype 3 (lower corridor). SM15, human footprint referred to morphotype 3 (Sala dei Misteri). CA8, human footprint referred to morphotype 3 (upper corridor). C72, handprint (lower corridor). SM44, finger traces (Sala dei Misteri). SM55, finger flutings on the clay floor (Sala dei Misteri). SM12, adult bear footprint (Sala dei Misteri). C12, immature bear handprint (lower corridor). CA12, well-preserved Canidae footprint (upper corridor) 
and a strongly convex lateral margin. The trace of digit I is highly adducted, and all the digit traces show an overall larger divarication and an apparent separation between adjacent digit trace couples II-III and IV-V. Morphotype 4 incorporates bigger footprints with an overall length of $22.80 \pm 0.42 \mathrm{~cm}$. Both the medial and lateral margins are straight and correlate with a less pronounced medial embayment if compared to that characterizing morphotype 3 . Digit tip traces are aligned, roughly parallel to each other and oriented forward parallel to the main footprint axis. Morphotype 5 encloses the biggest human footprints of the Bàsura Cave, with an overall length of $25.73 \pm 0.45 \mathrm{~cm}$ (Fig. 14.3c1). This morphotype shows slightly concave margins and a variably pronounced plantar embayment. On the whole, the footprints included in this morphotype appear more robust with respect to those of morphotypes 3 and 4 . They share the adducted digit I trace with morphotype 3 and the straight and forwardly oriented digit tip traces with morphotype 4 .

In the main gallery, some footprints referred to morphotypes 3, 4 and 5 are associated with subcircular, proximally tapered, trace interpreted knee imprints (e.g. Fig. 14.4, C41-C42). These imprints are sometimes associated with fore foot imprints, to which also result strongly aligned, and show the completely muscular structure of the joint and of the next regions.

In the same area, at least six handprints are preserved (Fig. 14.2). Handprints are mostly represented by isolated, didactyl to tridactyl digit prints and complete pentadactyl prints. These traces can be regarded as unintentional traces left during the exploration of the lower corridor, both during producers' progression and in stance phase, and interfere with forefoot imprints (e.g. Fig. 14.2, C72).

Heel imprints are mainly distributed in the proximal portion of the lower corridor and close to the left cave wall. These traces appear similarly oriented to each other and in some cases preserve the proximal portion of the medial embayment related to the plantar arch. Sixteen isolated heel traces are also preserved in the innermost room (Sala dei Misteri) of the cave. Ten of these traces are grouped in a small area of about $1 \mathrm{~m}^{2}$. These traces mimic the morphology of the heel of the producer and in some cases preserve the proximal portion of the medial embayment of the plantar arch. The mean width of the proximal portion of these traces resulted $5.67 \pm 0.12 \mathrm{~cm}$, a dimension comparable to that characterizing morphotype 2 (Citton et al. 2017).

\section{Finger Flutings}

Finger flutings are preserved in several sectors of the cave (e.g. Fig. 14.2, SM55). The most spectacular and continuous are visible in the Sala dei Misteri. On the terminal wall of the hall, cluster of flutings are imprinted into moonmilk, and it may be classified as both Rugolean (the fluter stands still while fluting, and each unit comprises more than one line) and Mirian (the fluter moves while fluting each unit, and each unit comprises more than one line) following Sharpe and Van Gelder's (2006) terminology. On the stalagmite concretion (acephalous sphinx or zoomorphic stalagmite) placed against the terminal wall of the karst room, the main group of 

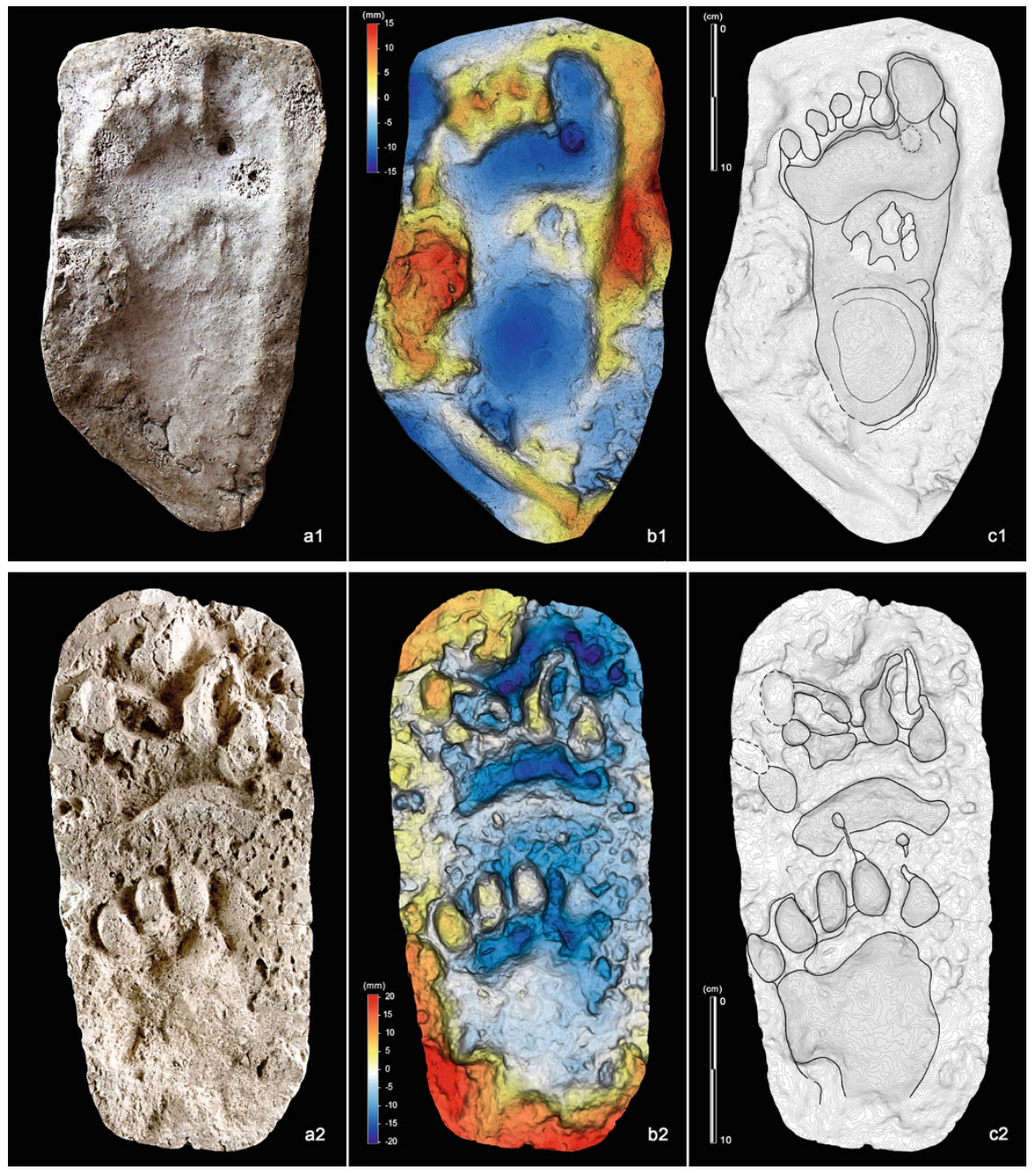

Fig. 14.3 3D scan of human and bear imprints; (a1) cast of the 1950s reproducing the human footprint C60 (morphotype 5) preserved in Sector A of the lower corridor (see Fig. 14.1); (b1) digital terrain model of the cast obtained from the HDI 3D Scanner; (c1) topographic profile with contour lines, obtained from b1 with interpretive draw. A superimposed partial canid track is recognizable in the metatarsal area of the human footprint; (a2) cast of the 1950s reproducing a manus-pes bear couple; (b1) digital terrain model of the cast obtained from the HDI 3D Scanner; (c1) topographic profile with contour lines, obtained from b2 with interpretive draw superimposed

finger fluting is recognizable. Most of them are of the Mirian type and have been imprinted by at least two individuals who have smeared soft clay on the stalagmite surface. The width of the I-IV finger group varies between 2.7 and $5 \mathrm{~cm}$. At the base of the stalagmite are recognizable sinuous lines left by the hands of a young individual (not exceeding 5 years - morphotype 1?), while in the medium-high 

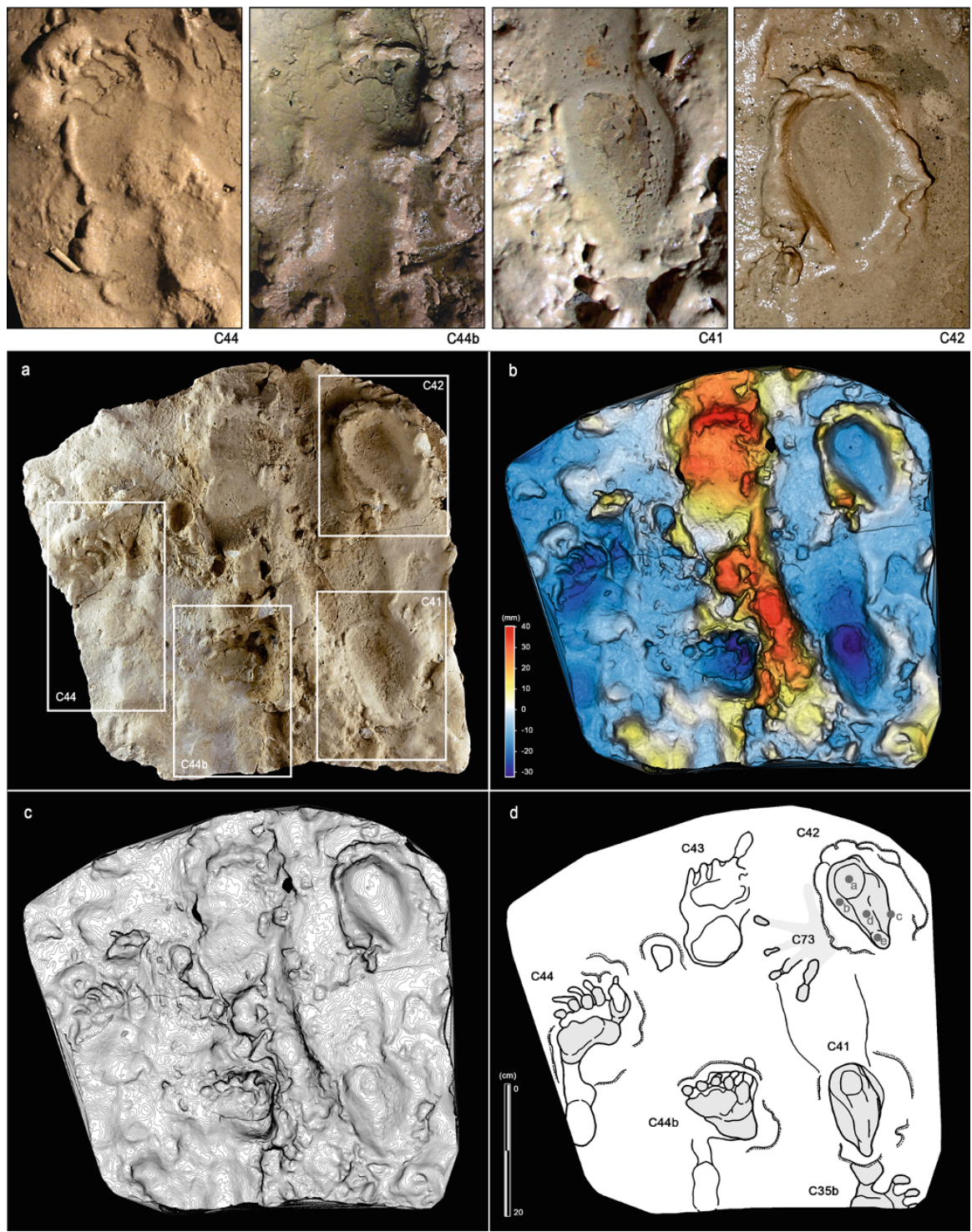

Fig. 14.4 Selection of semi-plantigrade and knee traces from the lower corridor of the Corridoio delle Impronte in the Bàsura Cave, indicating crawling locomotion of the producers. Semiplantigrade and metatarsal traces $(\mathrm{C} 44-\mathrm{C} 44 \mathrm{~b})$ and knee traces $(\mathrm{C} 41-\mathrm{C} 42)$ imprinted on a plastic, waterlogged muddy substrate; (a) cast of the 1950s reproducing two knee (C41, C42) and two metatarsal $(\mathrm{C} 44, \mathrm{C} 44 \mathrm{~b})$ traces preserved in the area B of the lower corridor (see Fig. 14.1); (b) digital terrain model obtained from the HDI 3D Scanner; (c) topographic profile with contour lines, obtained from $\mathrm{b}$; (d) interpretive draw. In the knee trace $\mathrm{C} 42$ are located the impressions of the patella $(a)$, vastus medialis $(b)$, fibular head $(c)$, patellar ligament $(d)$ and tibial tuberosity $(e)$ 
part, there are recognizable traces impressed by a larger individual (adolescent or subadult morphotype 3-4?). An ongoing analysis suggests working out the lines' overlay and underlays and hence temporal sequence of their compilation. Overlays tell the temporary sequence in which units in a cluster were fluted and the direction in which the cluster was composed. Some geometric compositions have been yet identified as the result of nonrandom superimpositions (trellis and sinuous lines).

\section{Clay Pits and Related Finger Traces}

In the Sala dei Misteri, some hole and pits are excavated on the clay floor. The holes are small $(10 \times 10 \mathrm{~cm})$ and can be interpreted as being used to casually extract clay with one hand. The two best-preserved pits are elliptical depressions $(70 \times 50 \mathrm{~cm})$ up to $30 \mathrm{~cm}$ deep, showing widespread traces of excavation with bare hands along the edges. The clues identified at Sala dei Misteri, suggesting that the adults and the younger child were collecting clay to cover the stalagmite, laid down only 2-3 m away from the clay pit.

\section{Animal Traces}

The palaeoichnofabrics generated by bears and canids was found in several sectors of the cave and is still under study and only briefly reported in this chapter.

Bear bioglyphs were made either by locomotion (Fig. 14.2, SM12-C12) (footprints and scratch marks: claw marks made on walls, cave floors and terrace slopes) or by habitation (hibernation or gestation nests, nest scratch marks).

Several well-preserved bear footprints belong both to juvenile and adult specimens with maximum length dimensions between $70 \mathrm{~mm}$ and $120 \mathrm{~mm}$ for the manual print and between $17 \mathrm{~mm}$ and $22 \mathrm{~mm}$ for the pedal ones (Fig. 14.3c2). These dimensions are smaller than those of the cave bear (Robua et al. 2018) and strictly comparable with those of the extant bear (Ursus arctos) to which we attribute them.

Some bear nests have been also identified, measured and surveyed. The majority of the nests were found very close to the cave walls. Of all the nests, only few were measurable $(\mathrm{N}=4)$, the remaining ones being partly destroyed or partly covered by flowstone. The distribution of the nests gives no indication of a pattern: sometimes they are overlapping (collective), sometimes they are lined up next to one another, or they are situated at considerable distance (tens of meters) from one another. The mean dimensions of the bear nests (length $140 \mathrm{~cm}$, width $90 \mathrm{~cm}$ and depth $25 \mathrm{~cm}$ ) indicate that their shape is ellipsoidal with low depth.

The diversity of the bear scratch marks from Bàsura Cave is complex. The claw marks, made either in sediment, on cave walls or on altered limestone, can be explained as exploration of the subterranean environment (or trying to escape from cave traps) and digging nests for hibernation. 
Several canid tracks are preserved on the floor of the Corridoio delle Impronte (Fig. 14.2, CA12). All the footprints can be easily separated into two main groups: the first with a stout general morphology $(\mathrm{L}, 9.5 \mathrm{~cm} ; \mathrm{W}: 9 \mathrm{~cm})$ and the second slender ( $\mathrm{L}, 9 \mathrm{~cm} ; \mathrm{W}, 8.5 \mathrm{~cm}$ ). The two morphotypes seem to correspond to manual and pedal prints. While canid tracks are well preserved and easily distinguishable, doubts remain concerning the precise canid species represented in the Bàsura Cave.

The ongoing statistical analyses seem to indicate that a single specimen entered the cave, but the interaction with the human footprints is still under study.

\section{Approaches and Methodologies}

All recognized tracks were analysed directly in the field through a morphological approach using available landmarks (Robbins 1985; Ledoux and Boudadi-Maligne 2015). The differential depth of each individual impression was analysed directly in the field to infer the complex and multiphase biomechanics. All footprints were drawn in the field on plastic film. All morphological and dimensional data collected in the field were double-checked by using photos and photogrammetric models. In addition, the original casts of the footprints from the 1950s were also used and analysed (Figs. 14.3 and 14.4).

\section{High-Resolution Digital Photogrammetry}

We use the photogrammetric method (Falkingham et al. 2018) to digitally acquire and reconstruct the ichnological material from the Bàsura Cave. Digital 3D models have been reconstructed for both humans and animal traces, including canid and bear footprints (see Citton et al. 2017 and Romano et al. 2019). For each single footprint, an average of 40 photos has been taken around the subject using a 24 Megapixel Canon EOS 750D (18 mm focal length). The software used to reconstruct the 3D photogrammetric model is Agisoft PhotoScan Standard Edition, version 1.4.0 (Educational License), which enables automatic generation of point clouds, textured and DSMs/DTMs and polygonal models and to georeferenced true orthomosaics from still images. High-resolution digital photogrammetry is based on multi-view stereo (MVS) and structure from motion (SfM) algorithms (Ullman 1979; Seitz et al. 2006); the accuracy for close-range photography is up to $1 \mathrm{~mm}$.

In the case of the lower corridor, a total of 327 photos for several angulations have been taken to cover all the trampled surface. The obtained model, with a dense cloud made by 60,742 points and a final mesh with over 31 million faces and 15 million of vertex, represents a really useful and crucial tool to recognize the different morphotypes and to interpret the complex locomotion. In addition, the separate high-definition 3D models of each single footprints help to recognize and describe 
the more solid and appropriate anatomical homologous point for morphological and morphometric analyses.

\section{D Scanning}

The principal cave sectors characterized by the highest concentration of ichnological data have been digitally acquired via laser scanner ScanStation2 Leica and ScanStation C10 Leica. Each scan was performed at $360^{\circ}$ (acquisition grid of the point cloud of $2 \times 2 \mathrm{~cm}$ a probe $7 \mathrm{~m}$ and in correspondence to the areas with the highest concentration of traces, an acquisition grid of $0.5 \times 0.5 \mathrm{~cm}$ probe $7 \mathrm{~m}$ ), with a total of 23 stations run using 38 targets. The acquired date was then processed via Leica Geosystems HDS Cyclone 9.1 software, with a final alignment error of $1 \mathrm{~mm}$ for the Corridoio delle Impronte and $2 \mathrm{~mm}$ for the model of the Sala dei Misteri.

The acquisition of the principal cave sector via high-definition laser scanning allows to contextualize the $3 \mathrm{D}$ photogrammetric model in a broader digital environment, improving both the knowledge and communication of the general framework. In addition, the obtained 3D models allow to digitally preserve really unique site as the Bàsura Cave, which, in the long time, could be damaged by both anthropic activities and natural geological processes.

The original cast performed in 1950 were digitally acquired via HDI Advance structured-light 3D Scanner R3x, with a resolution of $0.25 \mathrm{~mm}$ at $600 \mathrm{~mm}$ FOV (field of view). The data were processed with FlexScan 3D Software (Figs. 14.3 and 14.4).

\section{Morphometric Analysis}

Principal component analysis (PCA) represents a really powerful tool to summarize in a two-dimensional scatter plot the morphological variability for the studied specimens, even starting for a large number of morphological variables. The scores and loadings provided by the PCA help to identify the morphological variables that greatly influence the variance of the considered dataset and thus the more important anatomical landmarks for morphological description and grouping of similar objects.

A morphometric study has been performed on the best-preserved human and canid footprints. To build the raw dataset, we use the anatomical foot landmarks proposed by Robbins (1985 - for human) and Ledoux and Boudadi-Maligne (2015 for canids), and the log-transformed data that have been subjected to a principal component analysis in software PAST 3.10 were used (Hammer et al. 2001). The PCA result (Fig. 14.5) identified five different clusters of human footprints, with well-separated convex hulls, showing reduced explored morphospace. Thus, the morphometric analysis supports the morphological ones and strongly suggests that a minimal number of five individuals entered and explored the cave. 

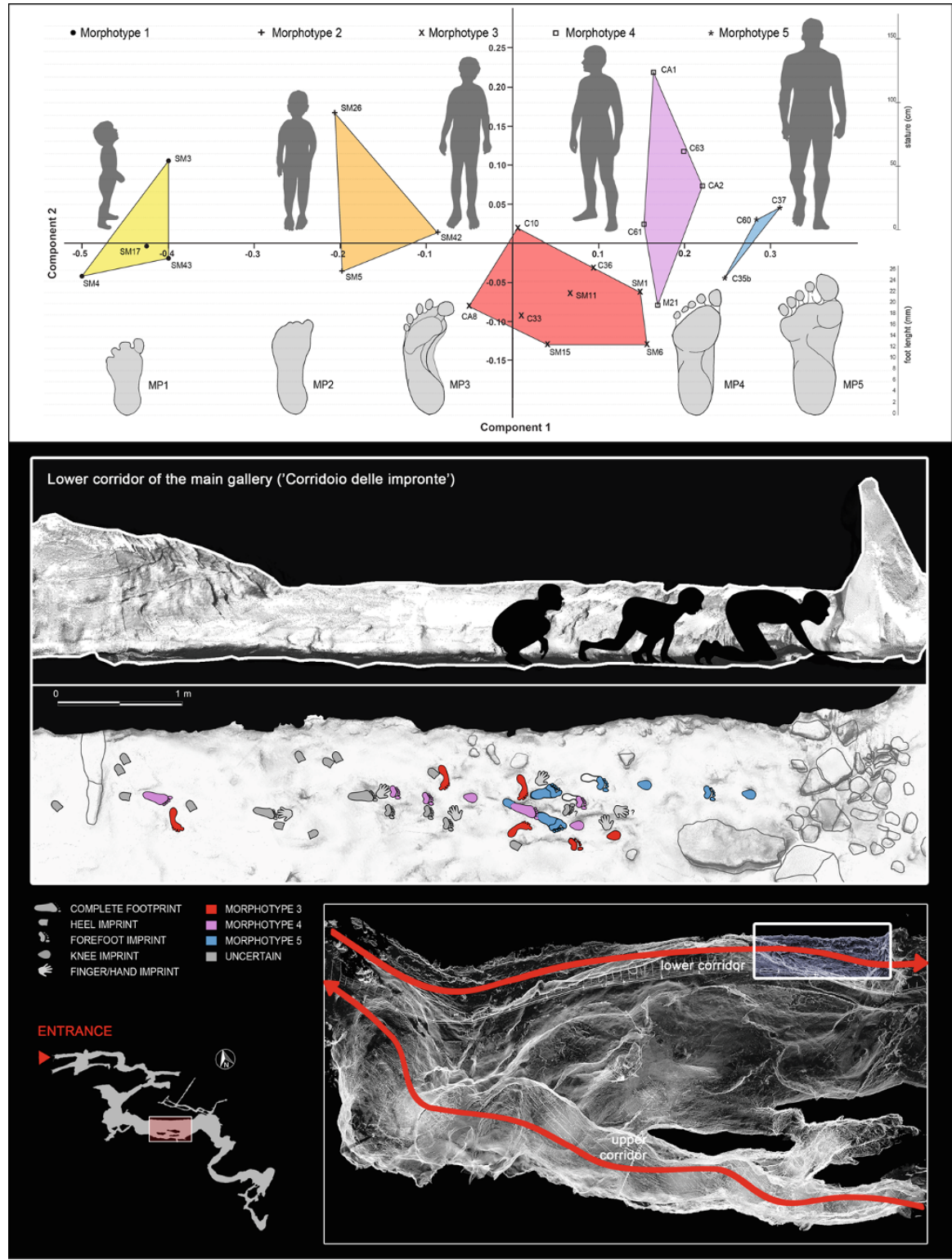

Fig. 14.5 Principal component analysis (PCA) based on the best-preserved footprints from the Bàsura Cave and reconstruction of crawling locomotion in the Corridoio delle Impronte. The five morphotypes to which footprints have been referred are shown. The sketch below illustrates the crawling locomotion adopted by the producers to cross the Corridoio delle Impronte (Sector B in Fig. 14.1) and access to the innermost rooms of the cave 


\section{The Archaeological Approach and New Absolute Dating}

Prehistoric human activity inside the Bàsura Cave has been the subject of speculation and interpretative theory since the discovery of the traces left in the Sala dei Misteri. Our understanding of it is still changing as excavations and modern scientific techniques yield more information. The first known excavation at Bàsura Cave was undertaken indeed in the 1950s in the Cimitero degli Orsi by the late Virginia Chiappella (1952), who investigated an approximately $70 \mathrm{~cm}$ thick palaeontological deposit of cave bear bones composed by two main accumulation levels and attributable to the Upper Pleistocene.

More recently, a further programme of excavations, led and conducted by two of the authors (ES and MZ), was carried out in 2016 with the aim of testing, for the first time, the existence of an anthropogenic deposit in the Sala dei Misteri and the thickness of the palaeontological deposit. The area selected for the test trench corresponds to the centre of the inner room, where the original clay surface has been trampled by the first explorers of the 1950s and during the construction of the touristic pathway, and no other traces except for modern boot sole imprints are preserved. The excavation grid has been positioned in correspondence of some preserved charcoal traces on the above cave ceiling attributable to prehistoric anthropic activity. The clay deposit was excavated for an extension of $6 \mathrm{~m}^{2}$, and it has a depth of maximum ca $40 \mathrm{~cm}$. The deposit was carefully water-screened with 3 and $5 \mathrm{~mm}$ meshes; however, no traces of artefacts have been noticed, except for numerous charcoals from the first centimetres of the deposit usually located in correspondence of the ceiling traces above. Some animal bones have been collected and identified as belonging to Ursus spelaeus. Bones of cave bears are rare, badly preserved and pertain for the most part to infant and juvenile specimens; adult bears are represented only by few bones recorded in the lower levels. In all the investigated squares, numerous milk teeth are present highlighting how many bear cubs have died between few months of life and 2 years of age (Andrews and Turner 1992; Debeljak 1996). In addition, some Ursus arctos teeth have been found in the upper unit of the stratigraphic section.

The profile has been sampled for micromorphological, geoarchaeological and archaeobotanical (pollen analysis, charcoals) investigations. New radiocarbon dates have been produced and are in progress from charcoal (Pinus t. sylvestris/mugo) and bone samples (Ursus spelaeus) collected in the different excavated units (Romano et al. 2019: Table 14.1). Preliminary results $(12,310 \pm 60 \mathrm{BP}, \mathrm{GrA}-69,598$ and $12,370 \pm 60 \mathrm{BP}$, GrA-69,597 from charcoals) confirm the human presence in the cave in the time span of 12,720-12,110 calBC/12,830-12,165 calBC, while the cave bear bones belong to at least two main accumulation episodes dating, respectively, to $>48,500$ calBP (GrM-10,848), >45,000 BP (GrM-11,615) and 29,475-28,805 calBP (GrM-10,849: 25,090 \pm 120 BP). The last date shows that the Bàsura Cave of Toirano should be added to the list of MIS 2 cave bear sites known in Europe (Terlato et al. 2018). 


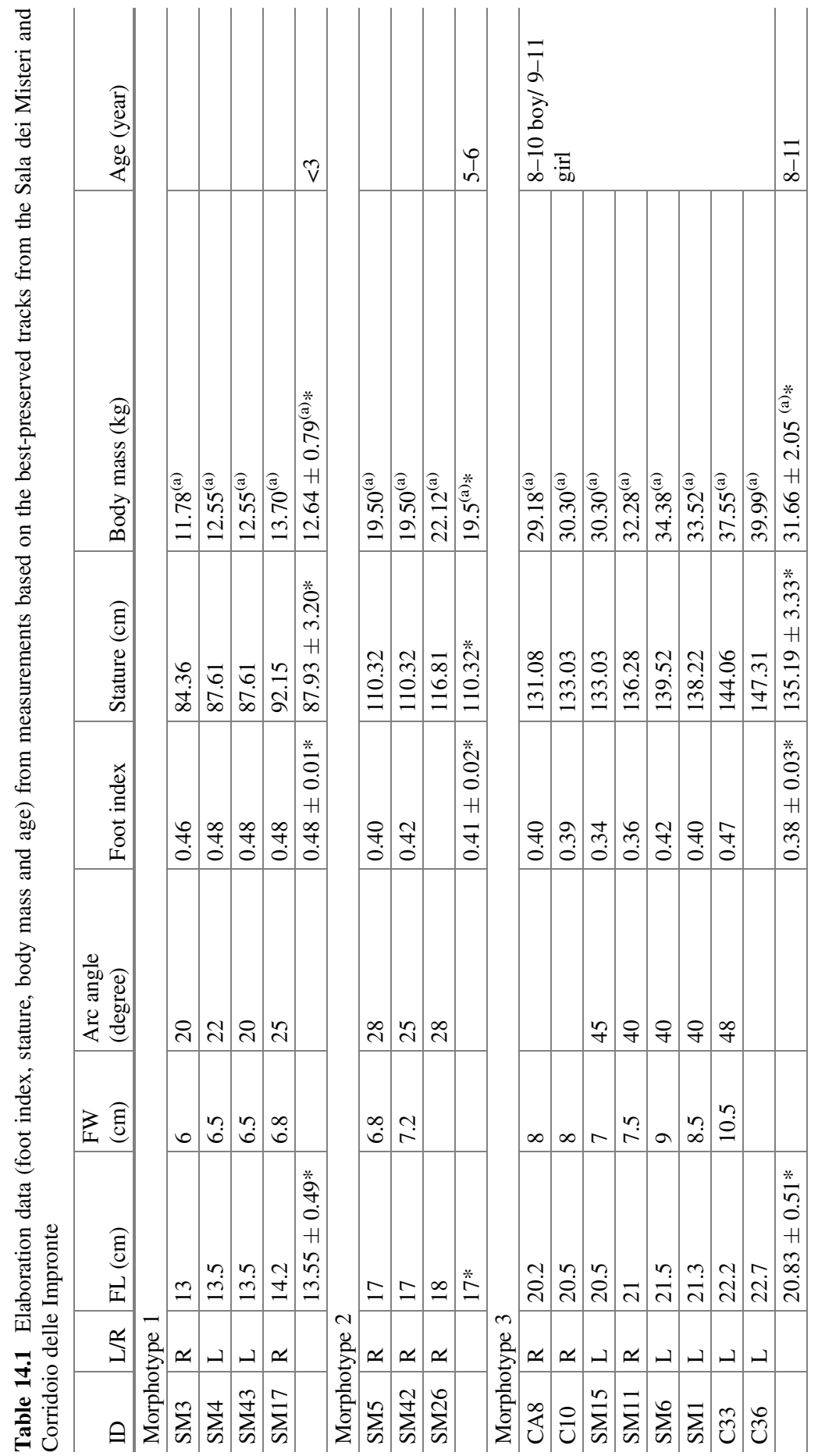




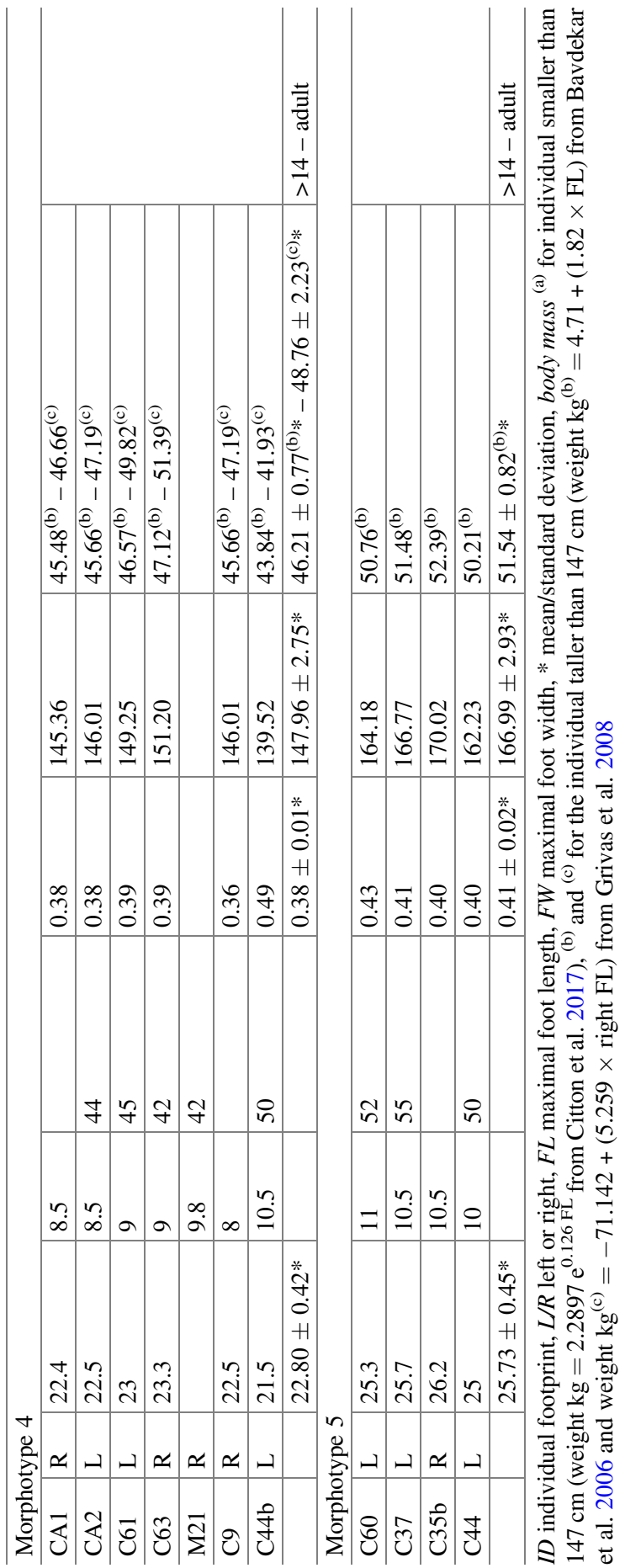




\section{Charcoal Remains and Insights on the Illumination of Caves}

The first palynological analyses carried out on the sediments recovered in the Cimitero degli Orsi had allowed the reconstruction of the vegetal landscape during the Upper Pleistocene (final period of MIS 3) in the area surrounding the Bàsura Cave (Arobba 1986; Arobba and Caramiello 2008). Results show a clear prevalence of herbaceous taxa typical of steppe formations (Artemisia, Centaurea, Carduus, Cirsium), accompanied by low values of arboreal shrub elements pertaining to the Scots pine forest (Pinus sylvestris), as well as more rare elements belonging to the mixed oak forest (Quercus deciduous t., Tilia, Corylus) and to the wetlands of the valley floor (Alnus and Salix). This situation is consistent with that found in other areas of southern Europe in the same period, characterized by a cold-dry climate, which may have been mitigated along the Mediterranean coast.

Although it should be taken into account that the pollen of Pinus sylvestris t. is constantly over-represented, the data seem to indicate the real distribution in the area of this species - currently distributed in the mountainous and subalpine planes during the Tardiglacial, a period during which the human frequentation of the cave is attested by charcoal remains.

More recent palynological investigations have shown a substantial overlap between the data described for the Cimitero degli Orsi and those conducted on a sedimentary sequence brought to light during the archaeological excavations carried out in 2016 in the Sala dei Misteri, located a few meters away.

On the surface level of the Sala dei Misteri series, i.e. in the first 3-4 cm, were found 56 fragments of charred wood of variable dimensions $(3-65 \mathrm{~mm})$, dated between 12,370 \pm 60 (GrA-69,597) and 12,310 \pm 60 (GrA-69,598) uncalBP (see Section The Archaeological Approach and New Absolute Dating). All belonged to the Scots pine/dwarf pine and are attributable to three species morphologically similar from the point of view of the anatomy of the wood (Schweingruber 1990): Pinus sylvestris (Scots pine), Pinus uncinata (mountain pine) and Pinus mugo (dwarf pine). The choice of harvesting this resinous wood with good flammability was certainly favoured by its presence in the immediate vicinity of the cave, as suggested by pollen analysis results.

In the prehistoric cave of Chauvet-Pont d'Arc (southern France), 171 charcoal remains have recently been recognized as Pinus sylvestris/P. nigra subsp. salzmannii/P. mugo/P. uncinata, and part of them were interpreted as residues of torches for lighting used between 37,000 and 28,000 years BP, i.e. in periods prior to that of the human frequentation of the Bàsura Cave. This suggests that the pine genus was one of the most suitable entities for this type of use (Théry-Parisot et al. 2018).

In our study, more than $80 \%$ of the material from which the fragments are derived comes from young branches, less than $2-3 \mathrm{~cm}$ in diameter, based on the curvature of the annual growth rings (Dufraisse and García Martínez 2011). Gathered in small bundles, these twigs could therefore have been elements of torches to be lit in sequence to achieve weak but effective lighting: this method was also documented, for example, in the protohistoric salt mines of Hallstatt (Austria), where was used 
twigs of Abies alba (silver fir) characterized by a non-resinous wood which therefore produces poor smoke. This choice is consistent with the work in a mine in which the human presence is prolonged (Barth 1983; Ast 2001; Grabner et al. 2010). On the other hand, in the Bàsura Cave, where the stay of man could be of short duration, it is understandable the choice of Scots pine resinous wood, even if it is more fume producing.

Experimental archaeology tests have shown that small-calibre sticks are more efficient in terms of ease and time of ignition, as well as durability, than torches made from large branches, dispelling the hypotheses made from the 1950s to the present day.

Another interesting aspect concerns the discovery of a greater quantity of charred wooden remains in the deposit in correspondence of the carbon traces present on the ceiling walls of the cave (Giannotti 2008). This suggests that those places were probably areas where the torches used by the ancient Palaeolithic visitors would have been revived.

\section{Inferences from Human Tracks and the Reconstruction of a Scenery}

\section{The Human Trackmaker Identikit}

Human plantigrade tracks allowed us to estimate stature, weight and ontogenetic stage of the producers basing on the collected biometric measurements (Table 14.1) and the adopted formulas (Citton et al. 2017).

The group of track producers entering the cave comprised a 3-year-old child about $88 \mathrm{~cm}$ tall (morphotype 1); a child at least 6 years old and about $110 \mathrm{~cm}$ tall (morphotype 2); a preadolescent, between 8 and 11 years old, about $135 \mathrm{~cm}$ tall (morphotype 3); a subadult to adult about $148 \mathrm{~cm}$ tall (morphotype 4); and an adult about $167 \mathrm{~cm}$ tall (morphotype 5) (Fig. 14.5). Estimate of the stature for the morphotype 5 is also sustained by the results obtained considering the length of the tibia derived from the available kneeling traces. Our results concerning morphotypes 4 and 5, which are referred to adult individuals, are in agreement with the average stature suggested during the European Upper Palaeolithic (162.4 $\pm 4.6 \mathrm{~cm}$ for males and $153.9 \pm 4.3 \mathrm{~cm}$ for females) (Villotte et al. 2017).

Body mass estimates derived from footprints parameters suggest slender body size for all the trackmakers. Arch angle and footprint morphology suggest a possible male as trackmaker of the largest footprint group. For morphotypes 1,2, 3 and 4, any inference of gender result possible although the presence of almost a female (morphotype 4?) seems probable.

Digitigrade and semi-plantigrade footprints informed on the pedal postures and the behaviour of the producers passing through different sub-environments of the cave. Both these footprint types were in most cases traced back to the same type of 
producer by comparison with complete footprints indicating complete foot support during locomotion. Some semi-plantigrade footprints (e.g. Fig. 14.4, C44-C44b) show a strongly adducted trace of digit I and an apparent alignment with the other digits, probably because of the intra-rotation movements of the distal portion of the foot during the thrust phase. Footprints included in morphotype 3 show a peculiar pedal morphology. While the resulting morphology of digit I trace is explained by walking on a waterlogged substrate, the separation between digit pairs II-III and IV$\mathrm{V}$ allowed hypothesizing an inherited familiar trait or a pathological condition of the producer's feet. The producer was not incapacitated, showing the greatest mobility in the hypogeal environment.

\section{The Exploration of the Cavity}

The study of the tracks and their interaction with substrate allows us to reconstruct the main aspect of the cave exploration. In the initial part of the cave, no footprints were preserved, so we hypothesize that after a walk of approximately $150 \mathrm{~m}$ from the original opening of the cave and a climb of about $12 \mathrm{~m}$, the group arrived at the Corridoio delle Impronte were the first main cluster is preserved (Fig. 14.1). They proceeded roughly in single file, with the smallest individual behind, and walked very close to the side wall of the cave, a safer approach also used by other animals (e.g. Canidae incertae sedis and bears) when moving in a poorly lit and unknown environment. The slope of the tunnel floor, inclined by about $24^{\circ}$, may have further forced the individuals to proceed along the only flat area in the lower corridor, a couple of meters from the left wall of the cave. About $10 \mathrm{~m}$ from the Corridoio delle Impronte, the cave roof drops to below $80 \mathrm{~cm}$, and members of the group were forced to crawl, placing their hands and knees on the clay substrate (Fig. 14.5).

After a few meters, the group leader stopped, impressing two parallel calcigrade footprints, possibly to decide on the next movement and proceeded to cross the parts where the cave roof was at its lowest. The other individuals also stopped at the same place as the leader and then proceeded along the same path by crawling and following the group leader, as indicated by the timing reconstructed from interactions between the tracks.

After passing a bottleneck of blocks and stalagmites, the party descended for about $10 \mathrm{~m}$ along a steeply sloping surface. The whole group traversed a small pond, leaving deep tracks on the plastic waterlogged substrate, climbed a slope of $10 \mathrm{~m}$ beyond the Cimitero degli Orsi and finally arrived at the terminal room Sala dei Misteri, where they stopped. On the walls, several charcoal traces, generated by the torches, are preserved.

Some charcoal handprints reaching up more than $170 \mathrm{~cm}$ on the roof of the Sala dei Misteri confirm that the tallest individuals (morphotypes 4 and 5) were able to touch this part of the gallery. The fact that their footprints are not preserved relates to the loss of the central portion of the hall floor. In the same room, the adolescent and children started collecting clay from the floor and smeared it on a stalagmite at 
different levels according to height, as suggested by the breadth and relative distribution of the finger flutings on the karst structure. During their sojourn in the innermost room of the cave, the young individual, which produced morphotype 2, imprinted ten clear heel traces (Citton et al. 2017), which are here interpreted as calcigrade tracks produced by a trackmaker who is momentarily standing still to excavate and manipulate clay as was also recorded for the Salle des Talons at Tuc d'Audoubert cave (Pastoors et al. 2015).

After stopping for several minutes (considering the quantity and ubiquity of the tracks), they exited and followed a route which did not always adhere to that followed on entry. After passing the small pond, they crossed the upper corridor following a more comfortable and safer route (Fig. 14.1). It is important to note that in the upper corridor, all the prints point in the direction of the exit while in the lower corridor, with the axis of the foot oriented parallel to the walls, most of the footprints are directed towards the interior of the cave (Fig. 14.5) (Romano et al. 2019).

\section{Bàsura Cave in the Regional Context}

The Palaeolithic human settlement in Liguria during the Late Glacial seems to be intensifying compared to the previous phases (Tomasso et al. 2014). In addition to scattered findings of Epigravettian lithic artefacts from open-air sites referable to short-term hunting camps, a more consistent evidence of long-term or pluristratified dwellings have been found in some shelters or caves, namely, in the archaeological area of Balzi Rossi (Grotta dei Fanciulli and Riparo Mochi), in the inner valleys of the Albenga Plain (Arma di Nasino, Arma dello Stefanin and Arma Veirana) and in the Finalese Area (Caverna delle Arene Candide).

These sites, mainly focused on hunting activities, are located both in the ends of the valleys and along the mountain terraces and ridges. At the Arma dello Stefanin, a cave located at the entrance of a valley rising towards the Alps, a high presence of ibex remains underlies the very specialized hunting vocation of the site (Barker et al. 1990). A high human mobility along the territory is also testified by the presence of a wide range of lithotypes used to make chipped stones; the lithotypes found in the Ligurian sites come from a very large area, which brackets, on the west, the Rhone Valley, in France, and, on the eastern side of the Italian peninsula, the Marche region (Negrino and Starnini 2003).

The most interesting behavioural features, involving social and ideological issues, concern however the burials. Burials have come to light at the Grotta dei Fanciulli (Gambier et al. 2001) and at the Caverna delle Arene Candide (Sparacello et al. 2018). Although, as for the Gravettian, the use of pierced sea shells as grave goods has always been widespread, new behaviours linked to funerary practices seem to arise. The Late Epigravettian levels of the Caverna delle Arene Candide, for example, have revealed a true cemetery dated at about $12 \mathrm{ka}$ calBP and referring to about 30 individuals, including a bisome burial as well as neonates, infants and juveniles; it shows a complex rituality, as highlighted by the presence of millstones 
and ochre painted pebbles, by different animal species, probably totemic, associated with the burials, and by a voluntary displacement of some human remains (RielSalvatore et al. 2018; Sparacello et al. 2018). The bisome burial discovered at the Grotta dei Fanciulli, which takes its name from this finding ( fanciulli means in fact children), belongs to two children, respectively, 4 and 5-6 years old; it has been dated at about $13 \mathrm{ka}$ calBP. The burial objects consist of about a thousand of perforated marine shells of Tritia sp. placed in correspondence to the pelvis and the proximal part of the femurs, probably sewn to clothes or belts, underlying how these young individuals were the subject of particular attention within the group (Gambier et al. 2001). Remains of children (jaw bones) were finally collected, in a secondary position, from the top units of the same deposit (Palma di Cesnola 2001).

The rich archaeological evidence referred to the Late Epigravettian likely witnesses a demographic growth and perhaps even an increased territoriality; new rituals, including the presence of a cemetery, suggest a deep restructuring of Palaeolithic society during the final stages of the Upper Palaeolithic, not only in Liguria but also all over in Italy and Europe (Pettitt 2011; Riel-Salvatore and GravelMiguel 2013), whose phenomenon is perhaps not extraneous to an introgression of a genetic component related to present-day Near Easterners, along with new cultural inputs, as suggested by recent aDNA outcomes (Fu et al. 2016). Concluding, what has been observed at the Bàsura Cave fits perfectly into this picture, enriching it with an evidence that even more underlines the basic and not secondary social role of the youngest individuals within the bands of hunter-gatherers at the end of Palaeolithic.

\section{Concluding Remarks}

Based on the integration of laser scans, sedimentology, geochemistry, archaeobotany, geometric morphometrics and photogrammetry, we have interpreted the evidence of a small Palaeolithic group of people explored a deep cave about $14 \mathrm{ka}$ calBP. Five individuals, two adults, an adolescent and two children, entered the cave barefoot and illuminated the way with a bunch of wooden sticks. Traces of crawling locomotion are well documented, and anatomical details recognizable in the crawling traces show that no clothing was present between limbs and the trampled sediments.

The tracks left in the Bàsura Cave indeed confirm us that hunter-gatherers' behaviour was not always driven by subsistence necessity, but as many ethnographic examples teach us, also by nonutilitarian activities.

However, what drove a small group of the Upper Palaeolithic with children younger than 3 years to venture into an unknown and dangerous environment like Bàsura Cave? Quite simply perhaps the innate and irresistible instinct of humans to the discovery, to leave the safe for the uncertain. The journey into the unexplored interior of the Earth of the restricted clan in the Bàsura Cave is a litmus test of how the predilection for the unknown and of the discovery is inextricably written in the human DNA. 
The same impulse and sense of wonder drove a group of young guys, in the first half of the twentieth century, to venture with torches in the Bàsura Cave, after 14,000 years and about 500 generations, to follow the father steps in the bowels of the Earth.

\section{References}

Andrews, P., \& Turner, A. (1992). Life and death of the Westbury bears. Annales Zoologici Fennici, 28, 139-149.

Arobba, D. (1986). Analisi palinologiche delle stalagmiti della grotta della Bàsura (Toirano, Liguria): primi risultati. Rivista di Studi Liguri, 51(4), 353-360.

Arobba, D., \& Caramiello, R. (2008). Il "Cimitero degli Orsi" della Grotta della Bàsura. Analisi palinologica del deposito. Toirano e la Grotta della Bàsura. In D. Arobba, R. Maggi, G. Vicino (Eds.), Atti del Convegno "Toirano e la Grotta della Bàsura", Toirano 26-28 ottobre 2000 (pp. 37-43).

Ast, H. (2001). Kienspan und Unschlitt, Beleuchtung im ländlichen Alltag. Kulturbeilage zum Amtsblatt der Bezirkshauptmannschaft Wiener Neustadt, 1-4.

Barker, G., Biagi, P., Clark, G., Maggi, R., \& Nisbet, R. (1990). From hunting to herding in the Val Pennavaira (Liguria - northern Italy). In P. Biagi (Ed.), The Neolithization of the Alpine Region (pp. 99-121). Monografie di Natura Bresciana, 13. Brescia: Museo Civico di Scienze Naturali.

Barth, F. E. (1983). Prehistoric salt mining at Hallstatt. Bulletin of the Institute of Archaeology, University of London, 19, 31-43.

Bavdekar, S. B., Sathe, S., \& Jani, P. (2006). Prediction of weight of Indian children aged up to two years based on foot-length: implications for emergency areas. Indian Pediatrics, 43, 125-130.

Blanc, A. C. (1960). Le palline d'argilla della Grotta della Basura. Rivista di Studi Liguri, 26, 9-25.

Blanc, A. C., Pales, L., \& Lamboglia, N. (1960). Le Vestigia Umane nella Grotta della Bàsura a Toirano. Bordighera: Istituto Internazionale di Studi Liguri.

Bruzzone, D., Bussallino, M., Castello, G., Maggiolo, S., \& Rossi, D. (2006). Measurement of the concentration of radon gas in the Toirano's caves (Liguria). Annali di Chimica, 96, 515-524.

Calandri, G. (2001). L'acqua calda di Toirano: caratteri idrogeochimici. In Gruppo speleologico Cycnus (Ed.), Atti V Convegno Speleologico Ligure “Toirano 2000”. Speleologia e carsismo nel Toiranese, Toirano 30 settembre - $1^{\circ}$ ottobre 2000, vol. I. (pp. 121-124). Comune di Toirano, Albenga: Stalla ed.

Chiappella, V. G. (1952). Orsi e uomini preistorici nella Grotta della Strega. Rivista del Comune (Genova), 29, 22-29.

Chiesa, R., Columbu, A., Audra, P., \& Bigot, J.Y. (2019). Compte rendu de sorties des 7 et 8 avril 2019 dans les grottes de Toirano (Ligurie, Italie). Unpublished report, Grotte di Toirano.

Citton, P., Romano, M., Salvador, I., \& Avanzini, M. (2017). Reviewing the upper Pleistocene human footprints from the 'Sala dei Misteri' in the Grotta della Bàsura (Toirano, northern Italy) cave: An integrated morphometric and morpho-classificatory approach. Quaternary Science Reviews, 169, 50-64.

De Lumley, M. A., \& Giacobini, G. (1985). Le impronte di piedi umani. Rivista di Studi Liguri, 51, 362-366.

De Lumley, H., Giacobini, G., Vicino, G., \& Yokoyama, Y. (1984). New Data Concerning the Dating and Interpretation of Human Footprints Present in the "Grotta della Basura" at Toirano (Savona, Northern Italy). Results of an international round table. Journal of Human Evolution, 13, 537-540.

Debeljak, I. (1996). Ontogenetic development of dentition in the cave bear. Geologija, 39, 13-77. 
Dufraisse, A., \& García Martínez, M. S. (2011). Mesurer les diamètres du bois de feu en anthracologie. Outils dendrométriques et interprétation des données. Anthropobotanica, 2, $1-18$.

Falkingham, P. L., Bates, K. T., Avanzini, M., Bennett, M., Bordy, E. M., Breithaupt, B. H., et al. (2018). A standard protocol for documenting modern and fossil ichnological data. Palaeontology, 61(4), 469-480.

Fu, Q., Posth, C., Hajdinjak, M., Petr, M., Mallick, S., Fernandes, D., Furtwängler, A., et al. (2016). The genetic history of Ice Age Europe. Nature, 534(7606), 200-205.

Gambier, D.H., Courty, M.-A., Crubézy, E., Kervazo, B., Tisnérat-Laborde, N., \& Valladas, H. (2001) La sépulture des enfants de Grimaldi (Baoussé-Roussé, Italie). Anthropologie et palethnologie funéraire des populations de la fin du Paléolithique supérieur. Documents préhistoriques, 14. Paris: CTHS éditions.

Giacobini, G. (2008). La Grotta della Basura e il "mito neandertaliano". In D. Arobba, R. Maggi, \& G. Vicino (Eds.), Atti del Convegno "Toirano e la Grotta della Bàsura", Toirano 26-28 ottobre 2000 (pp. 21-27). Florence: Istituto Italiano di Preistoria e Protostoria.

Giannotti, S. (2008). La grotta della Bàsura (Toirano): rilettura e aggiornamento dei dati archeologici. In D. Arobba, R. Maggi, \& G. Vicino (Eds.), Toirano e la grotta della Bàsura. Conoscere, conservare e gestire il patrimonio archeologico e paleontologico (pp. 233-246). Istituto Internazionale di Studi Liguri: Bordighera.

Grabner, M., Klein, A., Reschreiter, H., \& Barth, F. E. (2010). Wood supply of the bronze age salt mining site at Hallstatt, Austria. Mining in European history and its impact on environment and human societies. In P. Anreiter et al. (Eds.), Proceedings for the 1st Mining in European History-Conference of the SFB-HIMAT, 12-15 November 2009 (pp. 171-176). Innsbruck: University Press.

Grivas, T. B., Mihas, C., Arapaki, A., \& Vasiliadis, E. (2008). Correlation of foot length with height and weight in school age children. Journal of Forensic and Legal Medicine, 15, 89-95.

Hammer, Ø., Harper, D. A. T., \& Ryan, P. D. (2001). Past: Paleontological statistics software package for education and data analysis. Palaeontologia Electronica, 4(1, 4), 9. http://palaeoelectronica.org/2001_1/past/issue1_01.htm. Accessed 16 Feb 2020.

Lamboglia, N. (1960). Le vestigia umane nella grotta della Bàsura a Toirano. Rivista di Studi Liguri, $26,1-5$.

Ledoux, L., \& Boudadi-Maligne, M. (2015). The contribution of geometric morphometric analysis to prehistoric ichnology: The example of large canid tracks and their implication for the debate concerning wolf domestication. Journal of Archaeological Science, 61, 25-35.

Maineri, D. (1985). La scoperta della Grotta della Bàsura a Toirano. Atti della Tavola Rotonda "La Grotta preistorica della Bàsura", Toirano, 11-13 novembre 1983. Rivista di Studi Liguri, 51, 315-320.

Menardi Noguera, A. (1984). Nuove osservazioni sulla struttura del massiccio del Monte Carmo. Bollettino della Societa Geologica Italiana, 103, 189-203.

Molleson, T. I. (1985). The antiquity of human footprints of Tana della Bàsura. Atti della tavola Rotonda "La Grotta preistorica della Basura", Toirano 11-13 novembre 1983. Rivista di Studi Liguri, 51, 367-372.

Molleson, T. I., Oakley, K. P., \& Vogel, J. C. (1972). The antiquity of human footprints of Tana della Bàsura. Journal of Human Evolution, 1, 467-471.

Morse, S. A., Bennett, M. R., Liutkus-Pierce, C., Thackeray, F., McClymont, J., Savage, R., \& Crompton, R. H. (2013). Holocene footprints in Namibia: the influence of substrate on footprint variability. American Journal of Physical Anthropology, 151, 265-279.

Negrino, F., \& Starnini, E. (2003). Patterns of lithic raw material exploitation in Liguria from the Palaeolithic to the copper age. Préhistoire du Sud-Ouest, supplément, 5, 235-243.

Pales, L. (1960). Le Vestigia Umane nella Grotta della Bàsura a Toirano. Rivista di Studi Liguri, 24, 9-90.

Palma di Cesnola, A. (2001). Le Paléolithique supérieur en Italie. Grenoble: Éditions Jérôme Millon. 
Pastoors, A., Lenssen-Erz, T., Ciqae, T., Kxunta, U., Thao, T., Bégouën, R., Biesele, M., \& Clottes, J. (2015). Tracking in caves: experience based reading of Pleistocene human footprints in French caves. Cambridge Archaeological Journal, 25, 551-564.

Pettitt, P. (2011). The palaeolithic origins of human burials. Abingdon/New York: Routledge.

Riel-Salvatore, J., \& Gravel-Miguel, C. (2013). Upper paleolithic mortuary practices in Eurasia: A critical look at the burial record. In S. Tarlow \& L. Nilsson Stutz (Eds.), The Oxford handbook of the archaeology of death and burial (pp. 303-346). Oxford: Oxford University Press.

Riel-Salvatore, J., Gravel-Miguel, C., Martino, G., Maggi, R., Rossi, S., \& Sparacello, V. S. (2018). New insights into the Palaeolithic chronology and funerary ritual of caverna delle Arene Candide. In V. Borgia \& E. Cristiani (Eds.), Palaeolithic Italy: Advanced studies on early human adaptation in the Apennine peninsula (pp. 335-355). Leiden: Sidestone Press.

Robbins, L. M. (1985). Footprints. Collection, analysis, and interpretation. Springfield: Charles C. Thomas Publisher.

Robua, M., Mireab, I. C., Petculescub, A., \& Constantin, S. (2018). Palaeoichnology of an MIS 3 cave bear settlement - Urşilor Cave (Western Carpathians, Romania). Palaeogeography, Palaeoclimatology, Palaeoecology, 493, 126-135.

Romano, M., Citton, P., Salvador, I., Arobba, D., Rellini, I., Firpo, M., Negrino, F., Zunino, M., Starnini, E., \& Avanzini, M. (2019). A multidisciplinary approach to a unique Palaeolithic human ichnological record from Italy (Bàsura Cave). eLife, 8, e45204. https://doi.org/10.7554/ eLife.45204.

Schweingruber, F. H. (1990). Mikroskopische Holzanatomie. Formenspektren mitteleuropäischer Stamm- und Zweighölzer zur Bestimmung von rezentem und subfossilem Material. Anatomie microscopique $d u$ bois. Microscopic wood anatomy. Birmensdorf: Eidgenössische Forschungsanstalt für Wald, Schnee und Landschaft.

Seitz, S. M., Curless, B., Diebel, J., Scharstein, D., \& Szeliski, R. (2006). A comparison and evaluation of multi-view stereo reconstruction algorithms. In I. E. E. E. Computer Society (Ed.), Proceedings of the 2006 IEEE Computer Society Conference on Computer Vision and Pattern Recognition (CVPR'06), New York, 17-22 june 2006 (pp. 519-528). New York: IEEE. https:// doi.org/10.1109/CVPR.2006.6.

Sharpe, K., \& Val Gelder, L. (2006). The study of finger flutings. Cambridge Archaeological Journal, 16(3), 281-295.

Sparacello, V. S., Rossi, S., Pettitt, P., Roberts, C., Riel-Salvatore, J., \& Formicola, V. (2018). New insights on Final Epigravettian funerary behavior at Arene Candide Cave (Western Liguria, Italy). Journal of Anthropological Sciences, 96, 161-184.

Terlato, G., Bocherens, H., Romandini, M., Nannini, N., Hobson, K. A., \& Peresani, M. (2018). Chronological and Isotopic data support a revision for the timing of cave bear extinction in Mediterranean Europe. Historical Biology, 31(4), 474-484. https://doi.org/10.1080/08912963. 2018.1448395.

Théry-Parisot, I., Thiébault, S., Delannoy, J. J., Ferrier, C., Feruglio, V., Fritz, C., Gely, B., Guibert, P., Monney, J., Tosello, G., Clottes, J., \& Geneste, J. M. (2018). Illuminating the cave, drawing in black: wood charcoal analysis at Chauvet-Pont d'Arc. Antiquity, 92(362), 320-333.

Tomasso, A., Naudinot, N., Binder, D., \& Grimaldi, S. (2014). Unité et diversité dans l'Épigravettien rÉcent de l'arc liguro-provençal. In M. Langlais, N. Naudinot, \& M. Peresani (Eds.), Les groupes culturels de la transition Pléistocène-Holocène entre Atlantique et Adriatique, Séances de la Société Préhistorique Française, 3 (pp. 155-185). Paris: Société Préhistorique Française.

Tongiorgi, E., \& Lamboglia, N. (1954). La Grotta di Toirano. Bordighera: Istituto Internazionale di Studi Liguri.

Ullman, S. (1979). The interpretation of structure from motion. Proceedings of the Royal Society of London, B203, 405-426.

Villotte, S., Samsel, M., \& Sparacello, V. (2017). The paleobiology of two adult skeletons from Baousso da Torre (Bausu da Ture) (Liguria, Italy): Implications for Gravettian lifestyle. Comptes Rendus Palevol, 16(4), 462-473.

Webb, S., Cupper, M. L., \& Robbins, R. (2006). Pleistocene human footprints from the Willandra Lakes, southeastern Australia. Journal of Human Evolution, 50, 405-413. 
Open Access This chapter is licensed under the terms of the Creative Commons Attribution 4.0 International License (http://creativecommons.org/licenses/by/4.0/), which permits use, sharing, adaptation, distribution and reproduction in any medium or format, as long as you give appropriate credit to the original author(s) and the source, provide a link to the Creative Commons license and indicate if changes were made.

The images or other third party material in this chapter are included in the chapter's Creative Commons license, unless indicated otherwise in a credit line to the material. If material is not included in the chapter's Creative Commons license and your intended use is not permitted by statutory regulation or exceeds the permitted use, you will need to obtain permission directly from the copyright holder. 